\title{
MSMEs Sector in India: Current Status and Prospect
}

\author{
Dr. Ajit Singh \\ Assistant Professor, \\ Department of Economics, \\ M.M.H. College, Ghaziabad, Uttar Pradesh, India
}

\begin{abstract}
The Micro, Small, and Medium Enterprises (MSME) embody the foundation of an economy in nurturing a recognizable growth rate and for engendering employment juncture. This sector has been considered as a device of socio-economic development in many developing and developed economies. It contributes significantly to India's industrial production, export, employment, and generates an extensive entrepreneurial base. The pandemic strikes globally so as also impact badly MSMEs and after COVID-19, the sector assumes a pivotal role in driving the growth engine. This paper analyzes the definition of MSMEs, the role and performance of MSMEs in the current status, and various challenges and prospects associated with the sector in India. The study concluded that the pandemic adversely impacts MSMEs and the government should take proper measures to overcome its effect.
\end{abstract}

\section{KEYWORDS}

Micro, Small, and Medium Enterprises, current status, sector, role and performance, challenges, and prospects.

\section{INTRODUCTION}

It is globally acknowledged that MSMEs are the spinal bone of the economy. MSME sector has emerged as a very important sector of the Indian economy, committing markedly to employment creation, innovation, exports, and inclusive growth of the economy. A huge fragment of India's firms is small, informal, and work in the unorganized sector. Based on annual reports on MSMEs designate that the sector shares around 30\% of India's GDP and locate on conventional estimate employ all over $50 \%$ of industrial workers. MSMEs contribute about $40 \%$ of the overall export. Over $97 \%$ of micro-firms are part of MSMEs and $94 \%$ of firms are registered with the government. The sector is consistently growing over urban and rural areas and is equitably constitute in the trade, manufacturing, and service sector.The current coronavirus crisis (COVID-19) impacting MSMEs, which are the backbone of India's all-round development story, has felt a remarkable impact and faced critical disturbance. As MSMEs are an important part of the domestic and foreign value chain, the predicament of the sector is of deep perturb.

\subsection{Review of Literature}

Das, P.(2017) focuses on the huge growth potential and opportunities a variable in India for the development of the MSME sector, to identify important issues, challenges, and suggestions. He used secondary data. He discovered that the sector has exhibited enough resilience to assist itself in the strength of our traditional skills and expertise and by infusion of capital, new technologies, and innovative marketing strategies. Lama, P. (2014) analyzes the role and performance of MSMEs in the Indian economy and government policies as well as the various challenges and opportunities associated with MSMEs. She used a descriptive approach and secondary data. She found that the MSMEs need to improve their productivity and quality, reduce costs and innovate. To keep MSMEs on the right path and direction, it is necessary to emphasize the formulation of friendly policies, a conducive operating environment, proper finance, and modern technology for MSME. Manna, P. and Mistri, T. (2017) analyzed the existing scenario and trends of MSMEs in India. They used secondary data. They discovered that Micro enterprises occupied the leading position naturally in all states but some developed states are improving their small and medium enterprises also. The sector reduces regional disparity and creates regional development. Mohanty, J. J. (2018) investigated the present status and performance of the MSME sector and described the various measures taken by the government and SIDBI. The study found the MSMEs have revealed a good performance in the last few years. The role of the sector is growing rapidly and have become a thrust area for future growth for rural and urban development and its excitement have a lot of policy implication. Pachouri, A. and Sharma, S. (2016) established the current state of innovation in SMEs in India. The study also discussed the existing government policy framework and enables to support SMEs innovation in India. They found that despite numerous challenges, the sector has performed well. Unni, J. (2020) viewed the impact of COVID-19 on the Informal economy and MSMEs. He reveals that there is a requirement of macro-level forecast and estimates of the loss of employment, income, and GDP. This will help to visualize a plan of action and policies in short term. Zanjurne, P. (2018) concentrated on the performance of MSME and growth prospects. She used exploratory methodology and secondary data. She concluded that the MSME sector significantly contributes to exports, employment, and manufacturing output.

\subsection{Objectives of the study}

1. Investigate the theoretical basis, growth, and performance drift of MSMEs in the Indian economy;

2. Recognize the various issues and prospects correlated with MSMEs;

3. Assess the government action to rejuvenate the MSME sector;

4. Finally, make suggestions for further advancement of MSMEs in India.

\section{METHODOLOGY}

The study uses a descriptive-analytical approach. It is based on secondary data and information taken from various government reports, such as reports of the Ministry of MSME, handbook of statistics of Indian economy, issues of RBI, various research 
papers, journals, and websites of both public and private sector banks.

\subsection{Limitation of study}

National sample survey $73^{\text {rd }}$ round $(2015-16)$ has provided the latest data of MSMEs. Due to the inaccessibility of data, the study is limited to $2015-16$ data.

\section{DISCUSSION}

\subsection{Theoretical Basis}

Various definitions of MSMEs are prevailing internationally. Some countries used investment ceiling standards and some of them used the number of people employed. In India, MSMEs are mostly categorized based on investment in plant and equipment or machinery. The MSMED Act, 2006 has delivered the legal system for classifying the approach of 'enterprise' which combines institutions both service and manufacturing sectors, and has assorted the enterprises into three divisions viz., Micro, Small and Medium.

Table-1: Classification of MSME

\begin{tabular}{|l|l|l|}
\hline Categories & $\begin{array}{l}\text { Manufacturing } \\
\text { Enterprises } \\
\text { (Investment in Plant } \\
\text { and Machinery) }\end{array}$ & $\begin{array}{l}\text { Service } \\
\text { (Investment in } \\
\text { Equipment) }\end{array}$ \\
\hline Micro & Up to 25 lakh rupees & $\begin{array}{l}\text { Up to 10 lakh } \\
\text { rupees }\end{array}$ \\
\hline Small & $\begin{array}{l}\text { Above 25 lakh rupees } \\
\text { to 5 crore rupees }\end{array}$ & $\begin{array}{l}\text { Above 10 lakh } \\
\text { rupees to 2 crore } \\
\text { rupees }\end{array}$ \\
\hline Medium & $\begin{array}{l}\text { Above 5 crore rupees } \\
\text { to 10 crore rupees }\end{array}$ & $\begin{array}{l}\text { Above 2 crore } \\
\text { rupees to 5 crore } \\
\text { rupees }\end{array}$ \\
\hline Source: MSMED Act, 2006
\end{tabular}

Manufacturing Enterprises - The enterprises engrossed in the production of goods regarding any industry in the $1^{\text {st }}$ Schedule to the Industries (Development and Regulation) Act, 1951.

Service Enterprises - The enterprises engrossed in delivering services.

Table- 2: New Definition of MSME

\begin{tabular}{|l|l|l|}
\hline $\begin{array}{l}\text { Manufacturing and } \\
\text { Service Sectors }\end{array}$ & $\begin{array}{l}\text { Investment (In } \\
\text { INR) }\end{array}$ & $\begin{array}{l}\text { Turnover (In } \\
\text { INR) }\end{array}$ \\
\hline Micro Enterprises & Less than 1 crore & Under 5crore \\
\hline Small Enterprises & Less than 10crore & Under 50crore \\
\hline Medium Enterprises & Less than 20crore & $\begin{array}{l}\text { Under } \\
100 c r o r e\end{array}$ \\
\hline \multicolumn{2}{|l|}{} \\
\hline Source: RBI Gazette notification \\
\hline
\end{tabular}

During Unlock 1.0 the Union Cabinet sanctioned an economic package for MSMEs along with an expanded definition. The new definition combines manufacturing and service sector MSMEs, allowing them to enjoy the same benefits. The new definition expanded the criteria of investment and turnover of MSMEs.

\subsection{Present Growth and Performance of MSMEs in India}

MSMEs play a crucial role in the socio-economic development of the Indian economy. The sector has both registered and Informal sectors. The present paper measures the performance of the MSMEs based on major performance variables like total working MSMEs, employment generation, the market value of fixed assets, and share of MSME sector in total GDP from 2006-07 to 2015-16. In Table-3 the CAGR is highest for the market value of fixed assets, followed by the number of working units and employment. The statistics reveal that there is a high degree of relationship between the number of the working unit, employment, and market value of fixed assets. The share of MSMEs in the total GDP percentage is decreasing.

Table- 3: Growth of MSME Sector in India

\begin{tabular}{|l|l|l|l|l|}
\hline Year & $\begin{array}{l}\text { Total } \\
\text { Working } \\
\text { MSMEs } \\
\text { (Lakh No) }\end{array}$ & $\begin{array}{l}\text { Employment } \\
\text { (in Lakh } \\
\text { person) }\end{array}$ & $\begin{array}{l}\text { Market } \\
\text { Value } \\
\text { of } \\
\text { Fixed } \\
\text { Assets } \\
\text { (Rs in } \\
\text { crore) }\end{array}$ & $\begin{array}{l}\text { Share of } \\
\text { MSME } \\
\text { Sector } \\
\text { in Total } \\
\text { GDP } \\
(\%)\end{array}$ \\
\hline $\begin{array}{l}2006- \\
07\end{array}$ & 361.76 & 805.23 & $\begin{array}{l}868543 . \\
79\end{array}$ & 35.13 \\
\hline $\begin{array}{l}2007- \\
08\end{array}$ & 377.36 & 842.00 & $\begin{array}{l}920459 . \\
84\end{array}$ & 35.41 \\
\hline $\begin{array}{l}2008- \\
09\end{array}$ & 393.7 & 880.84 & $\begin{array}{l}977114 . \\
72\end{array}$ & 36.12 \\
\hline $\begin{array}{l}2009- \\
10\end{array}$ & 410.8 & 921.79 & $\begin{array}{l}103854 \\
6.03\end{array}$ & 36.05 \\
\hline $\begin{array}{l}2010- \\
11\end{array}$ & 428.73 & 965.15 & $\begin{array}{l}110593 \\
4.09\end{array}$ & 36.69 \\
\hline $\begin{array}{l}2011- \\
12\end{array}$ & 447.64 & 1011.69 & $\begin{array}{l}118275 \\
7.64\end{array}$ & 37.97 \\
\hline $\begin{array}{l}2012- \\
13\end{array}$ & 467.54 & 1061.4 & $\begin{array}{l}126876 \\
3.67\end{array}$ & 37.54 \\
\hline $\begin{array}{l}2013- \\
14\end{array}$ & 488.46 & 1114.29 & $\begin{array}{l}136370 \\
0.54\end{array}$ & 30.64 \\
\hline $\begin{array}{l}\text { Source: } \\
15 \\
\text { statistical Office, MOSPI }\end{array}$ & 510.57 & 1171.32 & 147191 & 30.74 \\
\hline $2015-$ & 633.88 & 1109.89 & 154349 & 28.77 \\
16 & $5.77 \%$ & $3.26 \%$ & $5.92 \%$ & $-1.98 \%$ \\
\hline
\end{tabular}

From figure 1 it is evident that the GVA of MSMEs has grown at a declining rate. The sector growing with about a 3 percent annual growth rate. In 2012-13 GVA growth rate is 15.27 to 7.62 in 2015-16. 


\section{ANNUAL GROWTH PERCENTAGE (\%)}

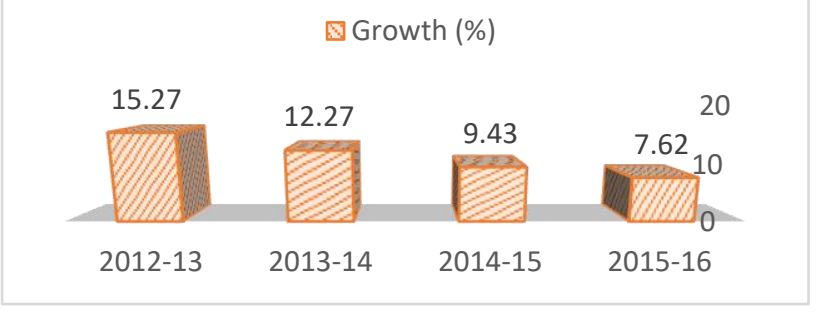

Figure 1: Growth Rate of MSME GVA (\%)

Source: Authors' computations based on MSME annual report 2017-18, Ministry of MSME. As per the National Sample Survey (NSS) $73^{\text {rd }}$ round during 2015-16, there were 633.88 lakh MSMEs in the country. These MSMEs are distributed in different sectors as trade has the highest share with $36 \%$ followed by other services with $33 \%$ and lastly manufacturing with $31 \%$ share. As shown in figure 2 .

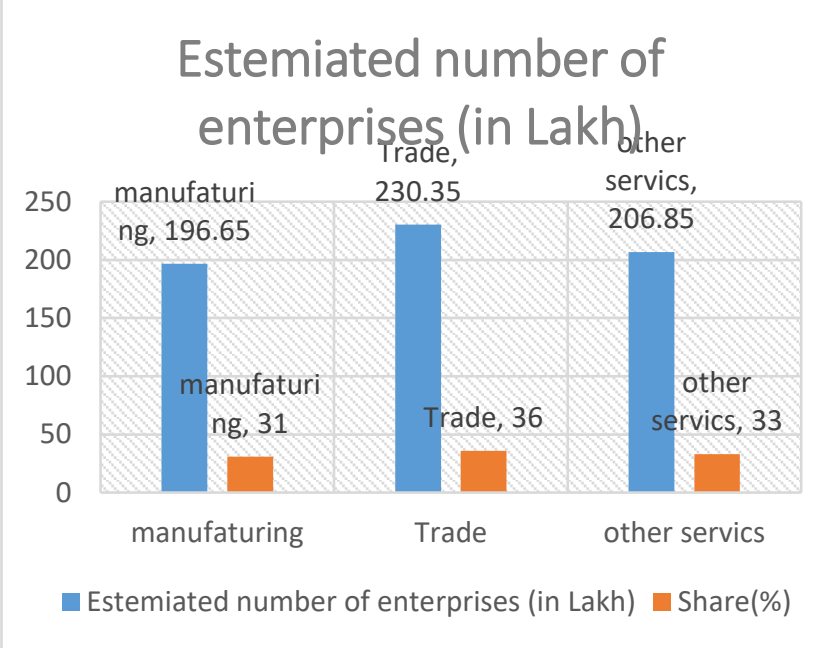

Figure 2: Distribution of Estimated MSMEs by Nature of Activity

Source: Authors' Computations based on MSME annual report 2019-20, Ministry of MSME. All India Manufacturers' Organization (AIMO) alliance with nine other industrial corporations, organized during 24-30 May 2020, and 42,525 MSMEs have participated. The survey divulged that about $35 \%$ of micro, small and medium enterprises and $37 \%$ of selfemployed personals have started closure on their businesses. They also found that over $70 \%$ of MSMEs might decrease their workers count to save their businesses and get back on track. AIMO's former president stated that the cause behind the shutdown of the units was not recent calamity alone, but prior demonetization and execution of GST over the last 3 years and the economic downturn which had already left them strained.

\section{DOMINANT ISSUES FACED BY THE MSMEs in INDIA}

\subsection{Issue of Raw Material}

A major issue that MSMEs have to assert is the appropriate raw material. The problem of raw material has assumed the form of a complete shortage, high cost, and poor quality of raw material. Due to complete lockdown, there is no availability of raw material also.

\subsection{Issue of Finance}

Finance is an important issue faced by the MSMEs. The sector contended the problem of finance mostly due to two reasons; firstly, attributable to low capital in the country. Secondly, difficulty in taking financial assistance from commercial banks and financial institutions. MSMEs are highly dependent on the cash economy, and due to pandemic restrictions, they were badly hurt.

\subsection{Issue of Marketing}

Marketing is one of the major issues faced by MSMEs. This sector often does not own any marketing corporation. Large-scale industries provide a quality product at a cheaper price. Consequently, it is very challenging to compete with multinational industries.

\subsection{Deficiency of Advanced Technology}

MSMEs holders used old production methods, which increased their production cost and lowered the quality of their product. Therefore, their product does not meet international standards.

\subsection{Issue of Under-utilized Capacity}

Many studies show that there is a tendency for under-utilization in micro and small enterprises. According to the All India Census of Small-Scale Industries, 50 to $40 \%$ of capacity was not utilized in MSMEs.

\subsection{Lack of Skilled Labour}

The deficiency of a skilled labor force and good managerial skills at low prices is another major issue for the MSMEs. The lack of skill formation and industrial training are other reasons for this.

\subsection{Other Issues}

In addition to the issues cataloged above, the micro, small and medium enterprises have been marred by several other issues also. These include lack of arranged market channels, incompetent knowledge of market conditions, unorganized creation of functions, inadequate accessibility of credit facility, confinement of infrastructure facilities, consisting power, technological desuetude, imperfect and improper supply of raw materials, and insufficient managerial and technical skills.

\section{PROSPECTS of MSMEs}

\subsection{Employment Formation}

This sector supplies huge employment opportunities at relatively lower capital costs. Manufacturing and service sector MSMEs are formatting contrasting and abundant amount of employment.

\subsection{Concentration on Customer Satisfaction}

Traditionally, MSMEs focused on liking, disliking, and test and preferences of the customer. However, these days they manufacture goods conforming to customer's expectations. 


\subsection{Captivate Foreign Investment}

The sector grows at an increasing rate and returns are also adequate. This can attract foreign investors to Indian MSMEs.

\subsection{Depreciation of regional Disparities}

The MSMEs situated in the rural areas are utilizing their manpower and are also developing the area, which is helpful in the removal of regional disparities.

\subsection{Expansion of Export}

There will be a huge demand for Indian products in the global market. So, it can improve the exports of the country.

\section{ACTION UNDERTAKEN BY GOVERNMENT}

5. The government has initiated collateral-free automatic loans up to INR 3 lakh crore.

6. The government has launched INR 20,000 crore as subordinate debt.

7. The government infused INR 50,000 crore equity through fund of funds.

8. The government has announced a partial credit guarantee scheme 2.0 for NBFCs.

9. Replacement of trade fairs and exhibitions and promoting Emarket linkages.

10. MSMEs outstanding from public sector undertaking (PSCs) to be issued in 45 days.

11. ZED certification scheme for financial support to MSMEs.

12. Global tenders will be dismissed in government acquisition tenders up to INR 200 crore.

\section{SUGGESTIONS}

The MSME sector should access low-cost finance to improve the flow of credit. To resist the competition with large enterprises from inside and outside, MSMEs require to construct capacities to evolve ICT and other instruments in decree to serve the flourishing market needs. Infrastructural development is essential for MSMEs, it should comprise plenty of infrastructural facilities like roadways, railways, waterways, and airways, proper channels of telecommunication, ample supply of power, and other facilities like Testing labs, Design center, Tool rooms, etc. The outdated technology prevents MSMEs from their potential growth. The sector has access to new and foreign technologies, along with assistance from large firms, low-cost ICT solutions, and better support for Research and Development. In this crisis scenario, the sector should provide discounts on interest rates and waive the loans of highly affected MSMEs. Schemes like Bima Yojna and PMEDY should cover the employees of MSMEs.

\section{CONCLUSION}

MSMEs have significantly contributed to the growth of the Indian economy. Its tremendous participation in Indian GDP, employment generation, exports, production, and industrialization of rural areas. The MSME sector is growing swiftly, but as well as facing numerous issues. To improve the condition government should implement proper policy measures. The outbreak distresses the sector badly, with the increase in numbers of enterprises about to close and much more cutting down their employee numbers to maintain their businesses. The government announced a stimulus for the sector to give it the right direction and path. The development of the MSMEs is critical for the future of the country. In the current scenario for the upliftment of the economy, the sector became the drive engine of the economy. If government further promotes MSMEs these MSMEs can brighten and shine the Indian economy more.

\section{Acknowledgment}

The authors are grateful to the anonymous referee for useful suggestions and comments to improve the quality of the article.

\section{Conflict of Interests}

The authors declared that no wrangle interests exist.

\section{Author's Contributions}

Both the authors contributed equally to the theoretical development, analysis, interpretation, and writing of the manuscript.

\section{Funding}

The authors received no financial support for the research, authorship, and/or publication of this article from any funding agency.

\section{Note}

The Compound annual growth rate (CAGR) is the mean annual growth rate of an investment over a specified time longer than one year.Gross Value Added (GVA) is estimated by the production approach.

\section{REFERENCES}

1. Das, P. (2017), "Micro, Small and Medium Enterprises (MSME) in India: Opportunities, Issues \& Challenges", Great Lakes Herald, Vol 11, Issue No. 1

2. Lama, P. (2013), "Micro, Small and Medium Enterprises (MSME) In India- Problems and Prospects", Business Studies, vol xxxiii \& xxxiv, 2013 \& 2014

3. Mama, P. and Mistri, T. (2017), "Status of Micro, Small and Medium Enterprises (MSME) in India: A Regional Analysis", IOSR Journal of Humanities And Social Science, Vol 22, Issue 9. PP. 72-82

4. Mohanty, J. J. (2018), "A Study on Micro, Small and Medium Enterprises (MSME) in India: Status and its Performance", International Journal of Research and Scientific Innovation", Vol v, Issue v

5. Pachauri, A. and S. Sharma (2016), "Barriers to Innovation in Indian Small and Medium-Sized Enterprises", ADBI Working Paper 588, HTTP:// www. Adb.org/publication/barriers-innovation-indian-small-andmedium-sized-enterprises/

6. Unni, J. (2020), "Impact of COVID-19 on Informal Economy: The Revival", The Indian Journal of Labour Economics (2020), 63 https://doi.org/10.1007/s41027-02000265-y

7. Zanjurne, P. (2018), " Growth and Future Prospects of MSME in India", International Journal of Advanced Engineering, Management and Science (IJAEMS), Vol 4, Issue 8

8. https://hindustantimes.com/analysis/msmes-is-critical-intimes-of-covid-19

9. https://livement.com/opinion/online-views/opionion-covid

10. https://indianexpress.com/article/india/rs-3-lakh-crorerelief-package-for-msme-but-govt-pvt-firms-owe-themmore-6410442/

11. https://economictimes.indiatimes.com/small-biz/smesector/over-one-third-msmes-start-shutting-shop-asrecovery-amid-covid-19-100-rs-unlikely-aimosurvey/artcles/76141969.cms 